NAVAL WAR COLLEGE

NEWPORT RI

\title{
A COMPARATIVE ANALYISIS OF THE OPERATIONAL LEADERSHIP OF ADMIRAL ISOROKU YAMAMOTO AND ADMIRAL CHESTER W. NIMITZ AT THE BATTLE OF MIDWAY
}

\author{
by \\ Linda K. Shultz \\ Commander, U. S. Navy
}

A paper submitted to the faculty of the Naval War College in partial satisfaction of the requirements of the Department of Joint Military Operations.

The contents of this paper reflect my own personal views and are not necessarily endorsed by the Naval War College or the Department of the Navy.


\author{
Faculty Advisor \\ Professor Charles Thomas \\ Department of Strategy and Policy
}
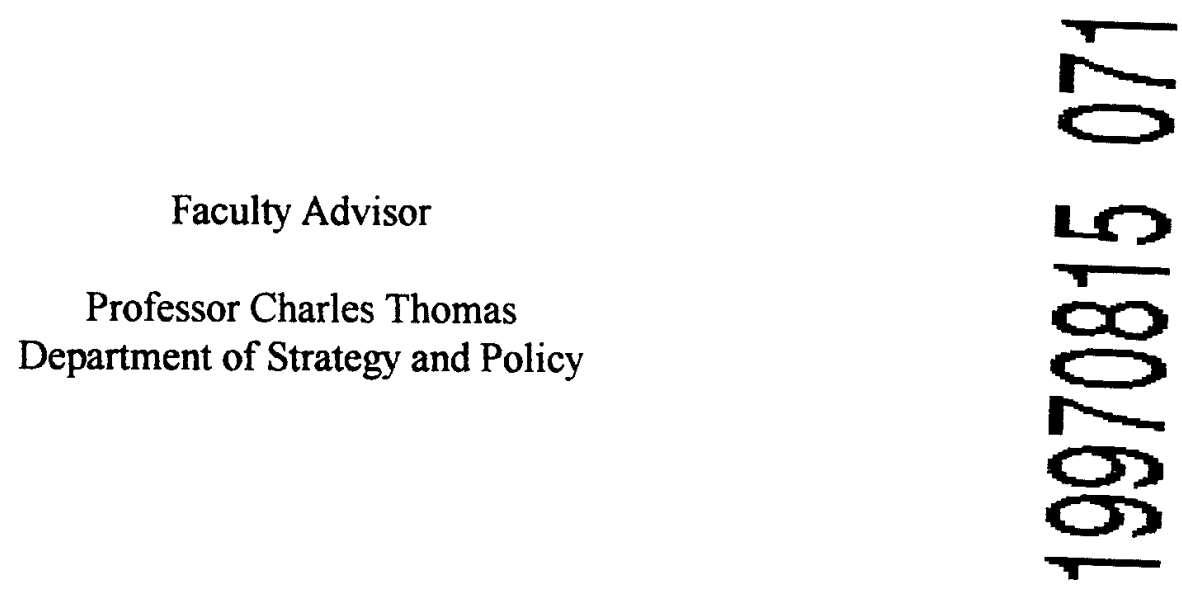
\{PRIVATE \}1. Report Security Classification: UNCLASSIFIED

\section{Security Classification Authority:}

\section{Declassification/Downgrading Schedule:}

4. Distribution/Availability of Report: DISTRIBUTION STATEMENT A: APPROVED FOR PUBLIC RELEASE; DISTRIBUTION IS UNLIMITED.

\section{Name of Performing Organization:}

\section{JOINT MILITARY OPERATIONS DEPARTMENT}

6. Office Symbol:

7. Address: NAVAL WAR COLLEGE

686 CUSHING ROAD

C NEWPORT, RI 02841-1207

8. Title (Include security Classification):

A Comparative Analysis of the Operational Leadership of Admiral Isoroku Yamamoto and Admiral Chester W. Nimitz at the Battle of Midway (U)

\section{Personal Authors:}

Linda K Shultz; COR, USA

\begin{tabular}{l|l} 
10. Type of Report: FINAL & 11. Date of Report: 16 May 1997
\end{tabular}

\section{Page Count: 22}

13. Supplementary Notation: A paper submitted to the Faculty of the NWC in partial satisfaction of the requirements of the JMO Department. The contents of this paper reflect my own personal views and are not necessarily endorsed by the NwC or the Department of the Navy.

14. Ten key words that relate to your paper: Operational Leadership, Principles of War, Midway, Nimitz, Yamamoto, planning, vision, character

15. Abstract:

Operational leadership can have a significant impact on the outcome of any operation or campaign and may often be the determining factor in the end result, irrespective of who holds the advantage. To illustrate this point this paper provides an analysis of the operational leadership of the opposing commanders at the Battle of Midway. By comparing Admiral Yamamoto's and Admiral Nimitz application of the principles of war, this paper demonstrates the significant impact of their operational leadership on the outcome of the Battle of Midway. Nimitz' clear vision, courage, and confidence in himself and his subordinates as well as his sound application of the principles of war overcame the overwhelming numerical and qualitative superiority of Yamamoto's Combined Fleet. Effective leadership is as significant in today's technologically advanced environment as it was during the world war II. The types of operational leadership challenges faced by Nimitz and Yamamoto must be faced by today's leaders, who must also carry the responsibility for ensuring the continued development of these elements of sound leadership in the operational leaders of tomorrow.

16.Distribution / Availability of Abstract:

Unclassified
$\mathrm{x}$

Same As Rpt
DTIC Users

\section{Abstract Security Classification: UNCLASSIFIED}

18. Name of Responsible Individual: CHAIRMAN, JOINT MILITARY OPERATIONS DEPARTMENT 


\section{INTRODUCTION}

The Battle of Midway is generally considered to have been the turning point in the Pacific War. In his introduction to A. J. Barber's historical analysis, Barrie Pitt states that Midway was "...the watershed. Before it, it seemed that nothing would ever halt the Japanese expansion; after it, the Allied advance on Tokyo was inexorable."1 For Japan, things would never be the same again. From fighting an aggressive war of conquest, her problem now became how to defend what she had; how to "...protect an ever shrinking periphery until at last she had been driven back where she started and beyond." ${ }^{2}$ The story of Midway is one of Japanese overconfidence and contempt for the enemy, poor planning and inadequate training, as well as one of American ingenuity, courage, and superior intelligence collection and application. According to H. P. Willmott in his analysis of the Pacific War strategies, "before the battle was joined there was no way the Japanese could have lost it, but once it began there was no way they could have won it."

What factors led to such a devastating outcome of this battle for the Japanese and such a victorious one for the United States? Despite having great numerical and qualitative superiority, the Japanese execution of a highly risky tactical deployment left her forces inferior to the enemy at the point of contact. ${ }^{4}$ Of great importance to the United States success was its superior intelligence gathering capability which revealed the Japanese campaign plan in sufficient time for the Pacific Fleet to prepare for the offensive. The key factor leading to the defeat of Japan at Midway, however, was the operational leadership demonstrated by the opposing commanders, Admiral Isoroku Yamamoto and Admiral Chester W. Nimitz. By comparing Yamamoto's and Nimitz' application of the principles of war, this paper will demonstrate the significant impact of operational leadership on the outcome of an operation or campaign. It is often the operational commander's leadership that will determine the end result, irrespective of who holds the 
numerical advantage. Effective leadership is as important in today's technologically advanced environment as it was at the Battle of Midway.

Operational leadership encompasses all the efforts of an operational commander to translate national or theater strategic aims and tasks into militarily achievable operational or strategic objectives. In order to accomplish this the operational commander must think operationally. Thinking broadly and understanding how each action fits into an overall design enables the commander to develop operational vision, the ability to determine how to accomplish political objectives through the employment of military forces. The vision of the operational commander provides his forces a clear sense of direction and mission. ${ }^{5}$ Vision enables the operational commander to recognize the kind of battle he is in so that he can develop an effective campaign strategy. It also allows him to see a path to victory. The commander must understand what constitutes mission accomplishment and how his forces will achieve it, what military conditions will produce the desired strategic objective and what sequence of events will bring about those conditions. It requires the combining of an effective planning procedure with an understanding of the capabilities of the forces available. ${ }^{6}$ Nimitz' clear vision and Yamamoto's lack of vision are demonstrated in their applications of the principles of war.

\section{OBJECTIVE}

The principle of objective is the most fundamental of the principles of war as it directs the military operation toward a clearly defined, decisive and achievable goal. In the planning stages the question of ends, ways, means and cost must be thoroughly analyzed. What military condition must be achieved operationally to support the strategic goal? What sequence of actions will most likely achieve that goal? How should resources be applied to accomplish that sequence of action? And finally, will it be worth the estimated cost in lives and resources? ${ }^{7}$

After the Battle of Coral Sea there was much uncertainty and disagreement as to where the next

Japanese offensive would occur. Initially, it was believed that the enemy's main effort would be 
in the southwest Pacific. Nimitz was prepared to concentrate his forces to hold open the line of communication to Australia. Intelligence information indicated that the northern and central Pacific theaters would remain quiet. However, in early May, intelligence estimates began indicating that the Japanese were planning a major offensive, but it was unclear where they would strike. By mid May, Nimitz had received sufficient intelligence to convince him that the main enemy effort would be made against Midway. While Nimitz fully accepted the validity of the intelligence information and was ready to act on it, it took him over a week to convince his superiors that Midway would be the primary target with a simultaneous diversionary attack against the Aleutians. ${ }^{8}$

Nimitz believed that the Japanese plan had two objectives: seize the Midway atoll for use as a logistics support base, and in so doing, provoke the Pacific fleet into a decisive battle. The Japanese would get their wish as Nimitz was determined to make a stand at Midway. ${ }^{9}$ His decision and the development of his plan to defend Midway were the result of his vision. The manner in which Nimitz addressed the expected attack on the Aleutians also demonstrates the vision which characterized his leadership. Believing that the Japanese would likely deploy a smaller force to the Aleutians, he considered making a stand there. A victory in the Aleutians would serve to boost morale in the fleet and on the home front. He also considered dividing his forces and resisting on both fronts. A final possibility would concentrate all forces at Midway and temporarily cede the Aleutians to Japan, an action that would be politically unpopular at home. Weighing his options and committed to his vision of making a stand, Nimitz deployed a small force to the Aleutians and concentrated his forces in defense of Midway.

Yamamoto failed most seriously at carrying out the principle of objective. As Prange states, "From the beginning, Operation MI was an operation with two heads, each arguing with the 
other. ${ }^{10}$ First, Yamamoto planned to attack and seize the Midway atoll. Second, he wanted to draw out and destroy the remains of the U. S. Pacific Fleet. These were fundamentally incompatible objectives. Storming and occupying an island required a firm schedule tied to conditions of nature, while an engagement against a mobile fleet called for great flexibility. Of the two objectives, Yamamoto stressed the wrong one. His primary mission focused on seizing Midway and the western Aleutians, with the vision that this action would lure out the Pacific fleet which his forces would then destroy. ${ }^{11}$ Had Yamamoto focused on eliminating the remainder of the U. S. Pacific Fleet, Midway could have been seized easily later. ${ }^{12}$

According to Agawa, the timing of the operation was of condern to Vice Admiral Nagumo, First Air Fleet, and Vice Admiral Kondo, Second Fleet. Having been deployed for three months, neither felt their forces were ready to sail right back into action. However, as the plan had already been approved and the timing set, there remained little chance at this point that they could delay the plan or question its advisability. ${ }^{13}$ By not consulting the two fleet commanders who would play leading roles at Midway, Yamamoto developed his plan without any accurate knowledge of the condition of these key forces. ${ }^{14}$

Yamamoto's original plan called for massing full strength against Midway. The strike against the Aleutians was added not only as a diversionary measure, but also in hopes that it would serve as the anchor of a protective arc passing from the Aleutians through the Midway area to the Torres Strait between New Guinea and Australia. Japanese control of the Aleutians would also preclude the United States from running a bombing shuttle from Dutch Harbor to Vladivostok to attack Japan if Russia should enter the war against Japan. ${ }^{15}$ Had Yamamoto in his planning analysis studied the topography of the Aleutian Islands, he should have ruled that out as a potential U.S. action as the islands were incapable of supporting large long-range bombers. ${ }^{16}$ 
Finally, if Yamamoto's vision was for the long desired great fleet battle, he should have delayed and pushed for the repairs to be made to the two carriers damaged at Coral Sea so that all six fleet carriers would have been ready for action. Yamamoto forced a plan for which the objectives were far from clearly defined or achievable.

\section{OFFENSIVE}

Offensive operations are the means by which a military force is able to seize and exploit the initiative while maintaining freedom of action and achieving decisive results. ${ }^{17}$

Yamamoto's plan to sail with his huge fleet of over 200 ships over a distance of several thousand miles to seize Midway and destroy the Pacific fleet battle was bold and aggressive. However, the plan was somewhat lacking in the true spirit of the offensive as the fundamental thinking behind the operation included advancing the Japanese defensive perimeter by securing an outer chain of bases to keep the enemy away from the Japanese homeland. ${ }^{18}$ Support for this effort was greatly enhanced as a result of the Doolittle raid on Tokyo. Yamamato's plan for the offensive against Midway was fatally flawed in that he failed to include branches and sequels to address possibilities such as the U.S. gaining advance knowledge of the Japanese approach, premature discovery of some portion of his huge fleet, or damage sustained to his naval air forces. Yamamoto's failure to develop and war game alternative plans to address these very real possibilities was a major contributor to the loss of the Combined Fleet's offensive spirit when the unforeseen occurred. ${ }^{19}$

\section{MASS}

The purpose of mass is the concentration of the effects of combat power at the place and time at which it will achieve decisive results. Massing effects rather than concentration of forces can enable a numerically inferior force to achieve decisive results while minimizing human loss and waste of resources. ${ }^{20}$ 
Nimitz did not allow himself to become immobilized by the immense size of the enemy forces he would face at Midway. While he could have abandoned Midway temporarily and moved his carriers and cruisers to the west coast for safety, he instead acted rapidly and aggressively, pitting his much smaller force against the numerically and qualitatively superior Japanese force. Recognizing that he did not have the resources for a head on confrontation, he ordered his task force commanders, Admirals Spruance and Fletcher, to place their forces on the flank of Admiral Nagumo's First Air Fleet. His vision required that his forces confront the Japanese air strike force as early as possible from a position of strategic advantage. ${ }^{21}$ That the Pacific fleet forces were concentrated from the outset and remained that way throughout the battle allowed them to achieve maximum strength both offensively and defensively. ${ }^{22}$

Yamamoto on the other hand made serious mistakes in his application of the principle of mass at Midway. Although he had a huge numerical superiority, his dispersal of his fleet assets invalidated that superiority and rendered it ineffective. On the surface his Midway strategy appeared to be a "classic double flank pincer's movement". However, each of his fleets converging on Midway was highly specialized and therefore not self-sufficient. In his overconfidence, Yamamoto assumed incorrectly that, in the very remote possibility that it should become necessary, his forces would just join up. By dividing his fleet into several directions and approaches, he greatly increased the likelihood of their premature detection. Rather than massing his ships against his primary objective, he further divided his strength by sending powerful fleet units to attack the Aleutians, thereby removing them a great distance from the area of the primary operation. Thus, Yamamoto gave up a key portion of the Combined Fleet to the Aleutians where, by Nimitz' vision and decision, no important naval engagement would be 
fought at that time. These absent forces might have made a difference to the final outcome at Midway. ${ }^{23}$

Yamamoto's dispersion of his forces was not limited to splitting them between Midway and the Aleutians. He further dispersed them within each of these operating areas. The Aleutian forces divided such that the Carrier Strike Force operated on it own, 300 miles in advance of the Screening Force of battleships. At Midway, the Carrier Force was positioned northwest of Midway; Yamamoto's Battleship Main Body was 300 miles back; the Invasion Force Main Body was south of Midway; and the Close Support Group with the invasion transports was southwest of Midway. This lack of concentration facilitated the destruction of the Carrier Force at Midway as the other forces were too far away to provide any assistance. ${ }^{24}$

Thus, while the Japanese possessed great numerical superiority in the general theater of operations, the Pacific Fleet possessed the numerical superiority at the point of contact. Midway was the second time in a single month (Coral Sea being the first) that Yamamoto had failed to emerge victorious despite having unused numerical superiority. ${ }^{25}$ Nimitz and Spruance, as well as Japanese experts have expressed agreement that Yamamoto's greatest mistake was his failure to concentrate his forces. ${ }^{26}$

\section{ECONOMY OF FORCE}

The principle of economy of force allocates only the minimum required combat power to secondary efforts. It requires the careful employment and distribution of forces to efforts such as limited attacks, defense, delaying actions and deception to allow achieving mass at a primary effort at the decisive point and time. ${ }^{27}$

Economy of force thus requires having enough force, but not too much force, to achieve the objective. Yamamoto, having committed his forces to the double mission of seizing Midway and drawing out the Pacific fleet to a decisive battle, sailed with his entire fleet of over 200 
ships. In so doing he failed to consider that he was wasting valuable fuel as well as deploying men in need of recuperation and training and ships in need of refitting. ${ }^{28}$ He should have been much more selective, bringing only those fleet elements truly necessary to meet his objective. The planned air strike against Midway was also excessively large for the objective and might have been better achieved by a smaller, experienced number, leaving the remaining crews available to meet any U.S. counteroffensive. ${ }^{29}$

Nimitz demonstrated better understanding and application of the principle of economy of force by deciding not to commit his battleships at Midway and by sending only a small force to the Aleutians. ${ }^{30}$

\section{MANEUVER}

The principle of maneuver places the enemy at a disadvantage by the flexible application of combat power. Its purpose is to keep the enemy off balance while protecting friendly forces and its application contributes to the ability to exploit success, allowing continued freedom of action and reducing vulnerability by posing new problems for the enemy. It is the movement of forces in relation to the enemy in such a manner as to secure positional advantage for delivering direct and indirect fires of the maneuvering force. ${ }^{31}$

It was Nimitz' opinion that the Japanese had established a pattern highlighted by failure to keep moving toward their objective to meet the enemy, spreading out in too many directions and taking on too much at Malaya, at Darwin, and in the Indian Ocean when all the time the main enemy of Yamamoto's Combined Fleet was the Pacific Fleet at Pearl Harbor, which they left alone after their hit and run raid. Nimitz considered the fact that the Japanese did not return to Pearl Harbor to complete the job to have been the greatest help for the Pacific fleet, "for they left their principal enemy with time to catch his breath, restore his morale and rebuild his forces. ${ }^{\text {"12 }}$

That Yamamoto tied his objective of finishing off the Pacific fleet with that of seizing Midway severely impacted Combined Fleet maneuver in that it eliminated the mobility and 
flexibility needed for a decisive sea engagement. Nothing in Yamamoto's planning addressed continuing the offensive if it met strong opposition. War games in preparation for Midway were run in a manner which ensured U. S. forces appeared incompetent. Therefore, when unexpectedly faced with the Pacific fleet's readiness for battle, Yamamoto's forces collapsed. Although he had superior surface ship and air numbers, once Nagumo's carriers were lost, Yamamoto made little further effort to continue the battle. Instead he turned and headed his entire force for home. ${ }^{33}$

In contrast, Nimitz' carrier strike force demonstrated the ability to seize and exploit the initiative by striking Nagumo's carriers when they were at their most vulnerable. Although Nagumo had been advised by the commander of Carrier Division 2, upon learning of the American carrier force location to the northeast, to launch an immediate attack, he chose to wait until he was prepared for a massive, coordinated strike with all of his planes. Turning his carriers to the wind to launch, his planes on the flight deck armed, fueled and finally ready to take off, he was caught by bombers from Yorktown and Enterprise which immediately destroyed three of his carriers, the fourth initially escaping but caught and destroyed shortly thereafter by dive bombers from Enterprise. Yamamoto then canceled the Midway operation and ordered a general retreat. $^{34}$

\section{UNITY OF COMMAND}

The principle of unity of command ensures unity of effort. All forces operate under a single commander who holds the authority to direct all forces to a common objective. Unity of effort requires coordination and cooperation among all the forces to achieve a common objective and is essential to unity of command. ${ }^{35}$

Yamamoto severely impacted his unity of command by sailing with his fleet in his flagship, the battleship Yamato. The necessity for maintaining radio silence prohibited him from 
exercising overall command of his forces which he could have easily accomplished from Tokyo as Nimitz did from Pearl Harbor. By taking his headquarters to sea, he forced his fleets to function independently and individually. The time lag between receipt of information on Yamato and the actual events ensured Yamamoto never held a current picture of the status of the battle. ${ }^{36}$

Because the operational commander is normally separated from the tactical action, he must have sufficient influence over his subordinate commanders that they will act as he would wish them to in unforeseeable circumstances. He must ensure that they understand his intent so that they will act in accordance with the requirements of the concept of operations even if they are not aware of what others are doing or do not understand the overall picture. At the Battle of Midway, Yamamoto failed to establish this relationship with Nagumo, his carrier task force commander. As a result, Nagumo delayed a decision to launch a strike because Yamamoto had not impressed on him the necessity of striking the American carriers first, at all cost. On the other hand, Nimitz had impressed Fletcher and Spruance with the necessity of striking first so that immediately upon locating Nagumo's carrier force, Spruance, who was known for caution, acted boldly in launching the half organized strike which destroyed Nagumo's carrier force. At this point Fletcher, having relocated his flag to the Astoria when Yorktown could no longer serve as flagship, recognized that he could not effectively exercise "tactical command of a carrier battle by remote control" and turned command of the battle over to Spruance. ${ }^{37}$

That Nimitz intuitively understood this principle is evidenced by the manner in which he established unity of effort in planning and executing Midway. Nimitz listened to his subordinates in planning meetings, open to their expert advice. The final planning conference for Midway was "...a gathering of dedicated, professional sailors for a cold, sober assessment of 
cold, sober facts. ${ }^{138}$ This was a last chance for them to do a face to face sizing up of the enemy, exchanging and comparing ideas and formulating an overall plan of action. In running this type of meeting, Nimitz instilled his vision in them and allowed them to make the plan of action their own. In so doing, he increased their loyalty and commitment. Clausewitz stated: "...when it is not a question of acting oneself but of persuading others in discussion, the need is for clear ideas and the ability to show their connection with each other. So few people have yet acquired the necessary skill at this that most discussions are a futile bandying of words; either they leave each man sticking to his own ideas or they end with everyone agreeing, for the sake of agreement, on a compromise with nothing to be said for it." ${ }^{39}$

Nimitz gave great consideration to command, control and communication efforts to ensure unity of effort. He personally visited Midway to inspect the facility and its existing communications capability. He stressed communications throughout the battle, ensuring critical information was received by all who would need it. Information necessary for making tactical decisions was transmitted in the blind so that the carriers could receive it yet remain undetected. ${ }^{40}$

Nimitz also fostered unity of effort through his personal actions and efforts. It was typical of him that in the middle of high level conferences and strategic level concerns, he still considered the officers and men who would perform the operation. For example, he sent a message to the deploying Task Force Sixteen for publishing at quarters, expressing his confidence in their courage, skill and ability to strike the enemy and wishing them "good hunting and good luck". ${ }^{41}$ On his trip to Midway he personally sought information from the commanders as to what they needed to defend the atoll and ensured that those requirements were satisfied. He also promoted them prior to the battle, demonstrating his confidence in their abilities. ${ }^{42}$ 
Another illustration of Nimitz' hands on attitude towards developing and maintaining unity of effort occurred when he visited the Pearl Harbor drydock in a successful effort to bring the shipyard workers on board with the necessity of getting the Yorktown ready for sea within three days, despite the original estimate that she would need ninety days. ${ }^{43}$

Once Nimitz was confident that his subordinates had adopted his vision and plan for Midway, he further reinforced unity of effort by demonstrating the courage to follow the principle of decentralized execution. This was particularly noteworthy in light of the lack of confidence Admiral King had expressed in Admiral Fletcher based on what King perceived as a lack of aggressive tactics at Coral Sea. ${ }^{44}$ Even when the CincPac staff questioned why Spruance was not in hot pursuit of the enemy on its westward course, but rather appeared to be heading east, Nimitz refused to intervene, stating "I'm sure Spruance has a better sense of what's going on out there than we have here. I'm sure he has a very good reason....We'll learn more about it in the course of time. From here we are not in a position to kibitz a commander in the field of action. ${ }^{.45}$

\section{SECURITY}

Security ensures the enemy is never given the opportunity to take the unexpected advantage. It increases freedom of action by reducing friendly force vulnerability to hostile acts and is enhanced by planning, as well as understanding the enemy's strategy, tactics and doctrine. Security includes risk management without promoting undue caution. ${ }^{46}$

Yamamoto underestimated the American will to fight as well as the level of U. S. intelligence efforts. The care, precision and emphasis on security which he had employed in preparation for Pearl Harbor were not in evidence in the planning for Midway. Too many people were aware of the plans. Preparations were not conducted in secret or camouflaged. Messages which allowed Nimitz to accurately estimate the strength of Yamamoto's force should have been transmitted in 
the highest security flag officers code, which U. S. intelligence had not yet been able to break. The Japanese finally changed their code system near the end of May, but by then Nimitz and the Pacific fleet had all their valuable information and were ready and waiting. ${ }^{47}$

One of Yamamoto's most serious security problems was the failure of Japanese intelligence. He did not know where the Pacific fleet carriers were or what strategy they might be pursuing. The sighting reports from long range aircraft proved unsuccessful because observers were unable to develop a pattern or keep track of them. Yamamoto's plans for pre-invasion scouting and reconnaissance were defective and inadequate. Those plans included a submarine screen between Hawaii and Midway so that the Combined Fleet would know if and when the Pacific fleet left Pearl Harbor. However, by the time the screen was in place, the Pacific fleet was already passed the line on its way to Midway. Yamamoto continued on to Midway believing the Pacific fleet was still at Pearl Harbor. ${ }^{48}$ Aerial reconnaissance of Pearl Harbor by sea plane was also a vital part of the plan. The planes were scheduled to meet Japanese submarines at French Frigate Shoals, refuel and fly on to Pearl Harbor. But when the submarines arrived, they found two American sea plane tenders at anchor as well as two American sea planes. Reconnaissance of Pearl Harbor which would have revealed only one carrier remaining in the harbor was canceled ${ }^{49}$

The Pacific fleet victory was in many ways a victory of intelligence. Yamamoto was guilty of failing to adequately protect the secrecy of his plans. The advance discovery of the planned offensive at Midway enabled Nimitz to recall Task Forces 16 and 17 from the south Pacific and have them in position to meet the Combined Fleet at Midway. Personally visiting Midway, Nimitz upgraded security requirements for defense of the atoll, including adding Marines, 
artillery, and aircraft as well as air searches over critical areas to ensure his forces were as secure as possible against air, naval, and amphibious attack. ${ }^{50}$

\section{SURPRISE}

The principle of surprise allows friendly forces to strike the enemy at a time and place or in a manner for which it is not prepared. Use of factors such as speed in decision making, sharing of information, effective intelligence, deception, application of unexpected combat power and OPSEC can result in a shift in the balance of power so that the success achieved is far greater than the effort expended. ${ }^{51}$

Achieving surprise was a vital element of Yamamoto's Midway plan. He counted on arriving in the Midway area unsuspected, as Nagumo had done at Pearl Harbor, until his attack was underway. He should have realized that he was now up against a United States at war and was facing a Pacific fleet that, because of the Pearl Harbor experience, was now highly alert. With all Yamamoto's experience in the United States, he should have been able to place himself in Nimitz' mind to estimate his probable actions and he should have developed a fairly accurate picture of U. S. capabilities. Less complacency and more effective reconnaissance might have enabled the Japanese to pinpoint American sorties, strength, course and destination, thereby ensuring Japanese preparedness for any counter offensive. However, Yamamoto and his subordinates were blinded by overconfidence, contempt for the enemy, and victory fever. ${ }^{52}$ Yamamoto fell into the trap of script writing in that he truly supposed that Nimitz and his forces would behave the way Yamamoto planned that they would. ${ }^{53}$

The breaking of the Japanese code JN25 by "Hypo" and the intelligence unit's clever trick to cause Japan to confirm that "AF" referred to Midway allowed Nimitz to learn of Yamamoto's plans with sufficient time to prepare for the Japanese offensive. Nimitz' confidence in his intelligence staff enabled him to act on the intelligence estimate despite pressure from numerous high level sources to prepare for the Japanese offensive in other theater areas. As Prange states, 
"Nimitz' concept of intelligence was dynamic: Facts were high grade ore to be sifted carefully, the pure metal of knowledge to be extracted and forged into a weapon to defeat the enemy." The breaking of the Japanese code allowed Nimitz to develop a successful strategy. Once he knew the Japanese were headed to Midway with Nagumo's carrier force in the lead, he knew when and how to fight. Planning an air battle, he left his battleships on the west coast. He brought every available carrier, successfully pushing for the amazingly rapid repair of Yorktown. In contrast, Yamamoto, suffering from overconfidence, sailed from Japan without waiting for repair of two of his carriers, having exerted no pressure to make them ready, convinced his fleet could beat the incompetent U. S. fleet without them. ${ }^{54}$

\section{SIMPLICITY}

Simplicity requires the development of clear, uncomplicated plans and orders which will be readily understood. Simple, clear plans and orders minimize the chance of misunderstanding and confusion, thereby facilitating execution of the mission in the stress, fog and friction of combat. $^{55}$

Yamamoto's Midway plan did not follow the principle of simplicity but instead was highly complex and contained many aspects that could have been eliminated. One factor which Yamamoto allowed to seriously complicate the situation was the continuation of the battleship/carrier dispute, despite the excellent performance of the Japanese naval air arm. Those favoring the battleships saw them as the premier weapon in a surface battle and could not see them in a secondary role. Those favoring carrier power believed the battleship to be of minimal use and that it took valuable assets away from the true striking force. In trying to support both views, Yamamoto's employment failed to get best of either view. None of the carriers was equipped with radar. Two new experimental models which were placed on the battleships might have provided the carriers early warning of the U. S. attack planes. Nimitz 
would later demonstrate how to best employ his battleships and his carriers as he would use the battleships to soften up the Pacific Islands and as a screen for his carriers. ${ }^{56}$

\section{CONCLUSION}

Having recognized that American ship construction would overwhelm the Japanese fleet by sheer force of numbers in the not too distant future, Yamamoto sought to engage the U. S. fleet in a decisive naval battle at the earliest opportunity. However, his total lack of vision and failure to adhere to any of the principles of war resulted in a Japanese disaster at Midway. With this failure he was forced to give up plans for a decisive naval engagement in remote waters in the near future. Instead, he would have to wait until Nimitz' Pacific fleet took the offensive. With the loss of his carriers and much of his naval air arm, Yamamoto was restricted to waters much closer to Japan and forced into a defensive role.

On the other hand, Clausewitz' comments on operational leadership in his chapter on military genius bring to mind the vision, courage and adherence to the principles of war by Admiral Nimitz: "What this task requires in the way of higher intellectual gifts is a sense of unity and a power of judgment raised to a marvelous vision, which easily grasps and dismisses a thousand remote possibilities which an ordinary mind would labor to identify and wear itself out in doing so. Yet even that superb display of divination, the sovereign eye of genius itself, would still fall short of historical significance without the qualities of character and temperament we have described." 57

While this paper has provided an historical comparative analysis of the operational commanders of the Battle of Midway, the significance of their differences in operational leadership and in how they applied the principles of war is as relevant today as it was then. 
The operational leadership challenges faced by Nimitz and Yamamoto at the Battle of Midway are the same ones faced by today's operational leaders. Nimitz used clear vision, courage, confidence in himself and his subordinates, and a sound application of the principles of war to overcome the overwhelming numerical and qualitative superiority of Yamamoto's fleet. His operational leadership was key to Midway's being the decisive battle which put Japan on the defensive and enabled the United States to shift to the offensive. Today's military leaders must continue to value these elements of sound leadership and to ensure they continue to develop them in our future operational leaders. 
${ }^{3}$ A. J. Barker, Midway: the Turning Point (New York: Ballentine Books 1971), 6

${ }^{2}$ Gordon W. Prange, Miracle at Midway (New York: McGraw Hill 1982), xii.

${ }^{3}$ H. P. Willmott, The Barrier and the Javelin, Japanese and Allied Strategies, February to June 1942 (Annapolis, MD: Naval Institute Press, 1983), 514.

${ }^{4}$ Ibid., 515 .

${ }^{5}$ Milan Vego, "Operational Leadership" (Newport, RI: Naval War College, NWC 4107, September, 1996), 1-4.

${ }^{6}$ Barney Rubel, "Operational Level Leadership" (Newport, RI: Naval War College, NWC 1032, January, 1996), 3-4.

${ }^{7}$ Joint Pub 3-0 Doctrine for Joint Operations, 1 February 1995, A-1.

${ }^{8}$ Willmott, 291-299.

${ }^{9}$ Ibid., 303.

${ }^{10}$ Prange, 376.

${ }^{11}$ Ibid., 31; Mitsuo Fuchida and Masatake Okumiya, Midway, the battle that doomed Japan (Annapolis, MD: U. S. Naval Institute Press, 1955) 234.

${ }^{12}$ Ibid., 376; Fuchida and Okumiya, 234.

${ }^{13}$ Agawa, 302.

${ }^{14}$ Fuchida and Okumiya, 63.

${ }^{15}$ Ibid., 23-24.

${ }^{16}$ Ibid., 376.

${ }^{17}$ Joint Pub 3-0, A-1.

${ }^{18}$ Fuchida and Okumiya, 61.

${ }^{19}$ Prange, 377.

${ }^{20}$ Joint Pub 3-0, A-1.

${ }^{21}$ Prange, 385.

${ }^{22}$ Fuchida and Okumiya, 234.

${ }^{23}$ Ibid., 233-234.

${ }^{24}$ Ibid.

${ }^{25}$ Willmott, xiii.

${ }^{26}$ Ibid., 378. 
${ }^{27}$ Joint Pub 3-0, A-1

${ }^{28}$ Agawa, 302.

${ }^{29}$ Prange, 382.

${ }^{30}$ Ibid.

${ }^{31}$ Joint Pub 3-0, A-2.

${ }^{32}$ Prang, 381.

${ }^{33}$ Ibid.

${ }^{34}$ E. B. Potter, Nimitz, (Annapolis, MD: U. S. Naval Institute Press. 1976), 105-106.

35 Joint Pub 3-0, A-2.

${ }^{36}$ Prange, 382.

${ }^{37}$ Rubel, 4.

${ }^{38}$ Prange, 102.

${ }^{39}$ Carl von Clausewitz, On War, ed. and trans. Michael Howard and Peter Paret, (Princeton, NJ: Princeton University Press, 1984), 71.

${ }^{40}$ Potter, 78.

${ }^{41}$ Prange, 106.

${ }^{42}$ Potter, 81 .

${ }^{43}$ Willmott, 338.

${ }^{44}$ Potter, 86

${ }^{45}$ Ibid., 99.

${ }^{46}$ Joint Pub 3-0, A-2.

${ }^{47}$ Prange, 380; Agawa, 360.

${ }^{48}$ Fuchida and Okumiya, 235-236; Edwin P. Hoyt, Yamamoto. the Man who Planned Pearl Harbor, (New York: McGraw Hill Publishing, 1990), 162.

${ }^{49}$ Edwin P. Hoyt, How they Won the War in the Pacific (New York:Weybright and Talley, 1970), 95.

${ }^{50}$ Fuchida and Okumiya, 232.

${ }^{51}$ Joint Pub 3-0, A-2. 
${ }^{52}$ Prange, 378.

${ }^{53}$ Fuchida and Okumiya, 246.

${ }^{54}$ Ibid., 384.

${ }^{55}$ Joint Pub 3-0, A-3.

${ }^{56}$ Prange, 380; Fuchida and Okumiya, 244.

${ }^{57}$ Clausewitz, 112. 


\section{Bibliography}

Agawa, Hiroyuki. The Reluctant Admiral, trans by John Bester. New York, NY: Kondansha International/USA, 1979.

Barker, A. J. Midway: the Turning Point. New York: Ballentine Books, 1971

Clausewitz, Carl von. On War, trans by Michael Howard and Peter Paret. 8th ed. Princeton, NJ: Princeton University Press, 1984.

Fuchida, Mitsuo and Masatake Okumiya. Midway, the battle that doomed Japan. Annapolis, MD: United States Naval Institute Press, 1955.

Hoyt, Edwin P. How they Won the War in the Pacific. New York: Weybright and Talley Publishing, 1970.

Hoyt, Edwin P. Yamamoto, the Man who Planned Pearl Harbor. New York: McGraw Hill

Joint Pub 3-0 "Doctrine for Joint Operations", 1 February 1995.

Potter, E. B. Nimitz. Annapolis, MD: United States Naval Institute Press, 1976.

Potter, John D. Yamamoto, the Man Who Menaced America. New York, NY: The Viking Press, 1965.

Prange, Gordon W. Miracle at Midway. New York, NY: McGraw Hill, 1982.

Rubel, Barney. "Operational Level Leadership." NWC 1032, Naval War College, Newport, RI: January, 1996.

Sun Tzu. The Art of War, trans by Samuel B. Griffith. New York, NY: Oxford University Press, 1963.

Vego, Milan N. "Operational Leadership." NWC 4107, Naval War College, Newport, RI: September 1996.

Willmott, H. P. The Barrier and the Javelin, Japanese and Allied Strategies, February to June 1942. Annapolis, MD: U. S. Naval Institute Press, 1983. 